Gbadebo J. Osemeobo

\title{
IMPACT OF TRADITIONAL PRACTICES ON MEDICINAL PLANT TRADE IN THE RAINFOREST OF NIGERIA
}

\begin{abstract}
A cross-sectional survey was used to assess the impact of traditional practices on trade in traditional plants within the rainforest of Nigeria. A questionnaire survey and marketbased observations were used to derive data from 110 stakeholders including: plant collectors, sellers, middlemen and traditional healers. Results of data analyses indicate that: (i) plants not suitable for cultural practices were not usually used for traditional medicine. (ii) Traditional management of the forests based on open access, restricted access and closed access rights could no longer protect habitats of medicinal plants. (iii) Breakdown of management practices in the forests was common because of a twin factor: violators of regulations were not being punished; and there were increasing disputes over land boundaries among communities. (iv) Medicinal plants on regular trade were in decline. Stakeholder participation in species rehabilitation in the forests and establishment of ex situ gardens may sustain the medicinal plant trade.
\end{abstract}

KEY WORDS: medicinal plants, cultural practices, traditional management, stakeholder participation, traditional healers

\section{INTRODUCTION}

Trade in traditional plants in Nigeria is cultural based. It is not limited to ethnic group systems. It is accessible to all cultures existing in the country. However, the uses of traditional plants are greatly influenced by traditional beliefs practised in the realm of rituals, magic and religion [Osemeobo 2005a]. Rituals are believed to enforce achieving cure. Medicinal plants in this study refer to plants that can both be used for healing and cultural ceremonies and festivals. It is widely believed that plants suitable in traditional medicine must have roots in the traditional cultures that were pivoted in myths and folklores. As a result, plants commonly used for cultural development are the ones used for traditional medicine [Posey, 1999, Osemeobo, 2009a]. There is therefore no clear cut difference between medicinal plants and plants used for cultural practices. In most communities, plants and animals not suitable for cultural practices are generally not used in traditional medicine [Osemeobo and Omeni, 2008].

Trade in traditional medicine has thrived in Nigeria because of push factors motivating huge acceptance by the people: (i) easy to access, cheapness, respect and privacy in treating patients [Sofowora, 1993]; (ii) application of trado-medical therapy for treatment of diseases and sickness that could not been treated in orthodox hospitals (multiple bone fractures, delayed labour in women) [NPC, 2000]; (iii) conformity with traditional culture based in taboos restricting traditional office holders from being treated by strangers[Chambers, 1999] particularly members of the opposite sex [Senanayake, 1999]; (iv) high overhead costs in attending orthodox health centres in distance 
places; (v) poor infrastructure (inadequate beds, drugs, medical officers, water and electricity) in most orthodox hospitals [UNSN, 2001]; and hostile attitudes of some medical workers to patients from rural areas.

Medicinal plants in the country are mainly collected from natural forests. They generate a vigorous volume of economic activity by meeting traditional medical requirements of over 124 million people on regular basis [Osemeobo, 2008].The collectors of medicinal plants from the forests are driven by profits with no regards for the conservation of species and habitats [Osemeobo, 2005b]. Poor management practices have made the resource base for the supply of medicinal plants fragile. Access to the forests by herbal collectors is under inferior land use rights. Under inferior user rights, a holder: (i) could be asked to withdrawal from collecting medicinal plants without prior notice, (ii) must renew permits to collect plants from landholding communities on seasonal basis and (iv) could be denied access to the forests anytime even within the period covered by permits [Osemeobo, 1993].

Over the past 15 years, decreasing supply of medicinal plants generated gaps in the traditional health care system and reduced incomes to healers [Osemeobo, 1991]. Even under this scenario, the forests are harvested beyond their carrying capacities because annual supply of medicinal plants form the forests is less than what the forests can regenerate within the same period. High demand of medicinal plants encouraged intensive and extensive harvest of choice species which has created serious concerns for species and habitat conservation [Osemeobo, 2001]. Rareness of some medicinal plants that are central to medical preparations (Acanthospermum hispidum, Vernonia amygdalina, Gloriosa superba, Psychotria vogelii, Aldornea cordifolia, Cissus arabides, Costus afer, and Cyclosonus afer) has increased prices in local markets [Osemeobo, 2009a]. Unfortunately, destructive harvesting practices (de-barking, cutting of roots of plants, uprooting herbs and seedlings and harvesting of flowers and immature fruits) contributed to die-back of species in natural forests (Pipper guineense, Baillonella toxisperma, Ricinus communis and Xylopia aethiopica) thereby hampering the flow of materials from the forests to sustain trade in medicinal plants [Osemeobo, 2001]. Unfortunately, lack of spatial data on trends of medicinal plant trade appeared to have closed up the opportunity for stakeholder motivation in commercial cultivation of high valued medicinal plants [FME, 2003]. These deep rooted cultural practices have largely impacted the supply and demand chains of medicinal plants [Osemeobo, 2009b].

\section{OBJECTIVES}

The objective of this study was to assess traditional practices that impact trade in medicinal plant within the rainforest of Nigeria. Specific objectives were to:

1. Identify and evaluate traditional practices in the management of the forests for commercial supply of medicinal plants; and

2. Examine how traditional practices can accommodate the conservation of medicinal plants.

\section{METHODOLOGY}

\section{The study areas}

The study has a spatial focus on the rainforest zone of Nigeria located between latitudes $4^{\circ} 30^{\prime} \mathrm{N}$ and $7^{\circ} 30^{\prime} \mathrm{N}$; and between longitudes $2^{\circ} 30^{\prime} \mathrm{E}$ and $9^{\circ} 30^{\prime} \mathrm{E}$ (Fig. 1).

\section{Sampling}

All the ten state capitals located within the rainforest zone of Nigeria were used for data collection. These were Abeokuta, Ado-Ekiti, Akure, Benin, Calabar, Enugu, Ibadan, Oshogbo, Owerri and Uyo. In each state capital, a reconnaissance survey was conducted and one open market where medicinal products were sold was randomly selected for data collection. 


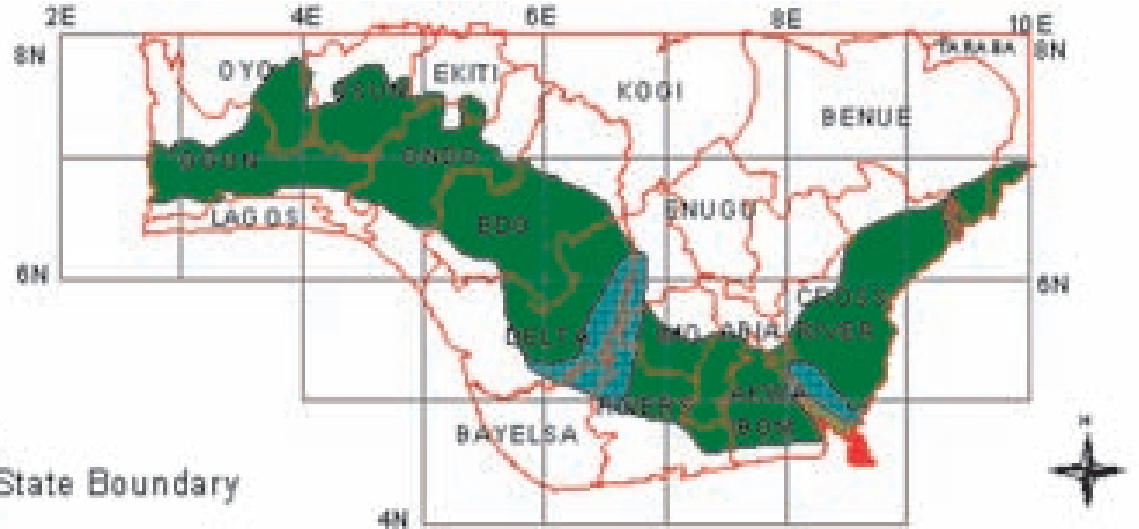

Freshwater Swamp Forest

$4 N$

Lowland Rainforest

Mangrove Forest and Coastal Vegetation

Montane Forest

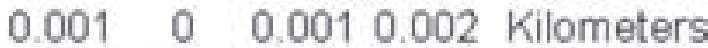

Fig. 1. The Lowland Rainforest Zone of Nigeria

\section{Data collection}

The data on which this study was based were collected between April 2009 and February 2010. Data were derived from 110 stakeholders including: plant collectors, sellers, middlemen and traditional healers using a structured questionnaire (Appendix 1). Physical observations were conducted in the open markets while discussions were held with groups of stakeholders. Medicinal plants were traded in products classified into four main types: reproductive propagules (flowers, fruits, seeds and nuts); vegetative structures (leaves, stems, roots and barks); whole plants (herbs) and plant exudates (gums and resins). Forty five marketable plant species and their products were observed during the survey.

\section{RESULTS AND DISCUSSION}

\section{Land tenure and access to medicinal plants}

Access to medicinal plants was determined by the land tenure system in vogue. Land tenure was the institutional arrangement guiding the ownership, allocation, control and use of land. The indigenous land ownership was communal made up of families with common ancestors or historically aligned. Families enjoyed clearly defined spatial user rights over different parcels of land common to them within the general land holding system. Access to medicinal plants under the communal land tenure system was free to members of a land holding family by birth or long settlement and through permits to nonmembers of land holding communities.

Analyses of the data in Table 1 indicate that: (i) access to medicinal plant harvest was not adequately controlled. Tenure regulations influenced access rights. Exploiters of medicinal plants had no obligation to conserve species and habitats. (ii) The least effective protection method for medicinal plants was the open access (37.7\%) and followed by restricted access (32.8\%) and closed (29.5\%). From the market survey it was clear that plant harvest was abused: immature flowers and fruits were harvested (Afromomum melagueta, Piper guineense); roots of plants were indiscriminately harvested (Garcinia kola, Hypoeses rosea); looping of trees with fruits was carried out (Piper guineense); debarking of trees did not 
Table 1. Traditional tenure regulations that negatively impact the medicinal plant trade

\begin{tabular}{|l|c|c|c|c|}
\hline \multirow{2}{*}{\begin{tabular}{c}
\multirow{2}{*}{$\begin{array}{c}\text { Location } \\
\text { of respondents }\end{array}$} \\
\cline { 2 - 5 }
\end{tabular}} & \multicolumn{3}{|c|}{ Respondent opinion on tenure regulations that negatively impact } \\
the medicinal plant trade (N = 110)
\end{tabular}

consider tree recovering. It was noticed that barks of trees that were formerly debarked but not fully healed were debarked again for the market (Khaya Ivorensis, K. grandifolia); and in most cases whole plant utilization were carried out (Alchornea cordifolia, Aspilia Africana, Ipomoea involucrata). About 95\% of the respondents in this study claimed that uncontrolled access rights to medicinal plants under the traditional land tenure regimes led to loss of species, decline and extirpation in the study area.

\section{Traditional forest management}

The forests where medicinal plants are harvested were grouped into three: privately owned, stool forests and community owned. The privately owned forests (with owner-user rights) and the stool forests (with exclusion rights) appeared to favour biodiversity conservation. The owner-user rights were exercised in privately owned fallow lands. Plants of socio-cultural and economic values were protected as long as the land remained in fallow. Respondents claimed that about $25 \%$ of medicinal plants on trade were derived from privately owned fallow lands on which access to other members of the community was excluded. The exclusion rights reduced the number of people who were allowed to gain access to resources devoted for specific community uses. The forests under the exclusion rights were stool forests: sacred grooves, bad bushes and royal forests managed through closed season and open season for those that enjoyed sequential rights of access. Transfer rights on these forests were forbidden to assure the stability of biological resources. According to respondents, only about $5 \%$ of medicinal plants in trade were supplied from these forests.

About $70 \%$ of medicinal plants were harvested from community forests. Table 2 presents respondent opinions on the causes of breakdown of regulations in community forests. The main reasons for poor management of community forests in Table 2 was due to the fact that: (i) the management system was being eroded by free-rider issues caused by: land fragmentation for agricultural production (26.4\%); (ii) poor monitoring of the forests: there were no paid guards to monitor the forests hence regulations could not be fully enforced (26.4\%); (iii) communities were loosing court cases against violators of community regulations 
Table 2. Causes of breakdown of community forest management

\begin{tabular}{|l|c|c|c|c|c|}
\hline \multirow{2}{*}{$\begin{array}{c}\text { Location of } \\
\text { respondents }\end{array}$} & \multicolumn{5}{|c|}{ Respondents opinions on causes of free-rider issues in community forests } \\
\cline { 2 - 6 }$(\mathrm{N}=110)$
\end{tabular}

(25.3\%); and (iv) community disputes over boundaries of settlements were common and these created gaps in forest control (21.9\%). Besides these factors, the forests under effective control of communities were becoming too small for effective management.
Fig. 2 was derived from the data in Table 2, and it presents the graphical illustration of the main causes of breakdown of community forest management which were mainly administrative laxity - the absence of forest patrol guards and land tenure issues that led to land fragmentation.

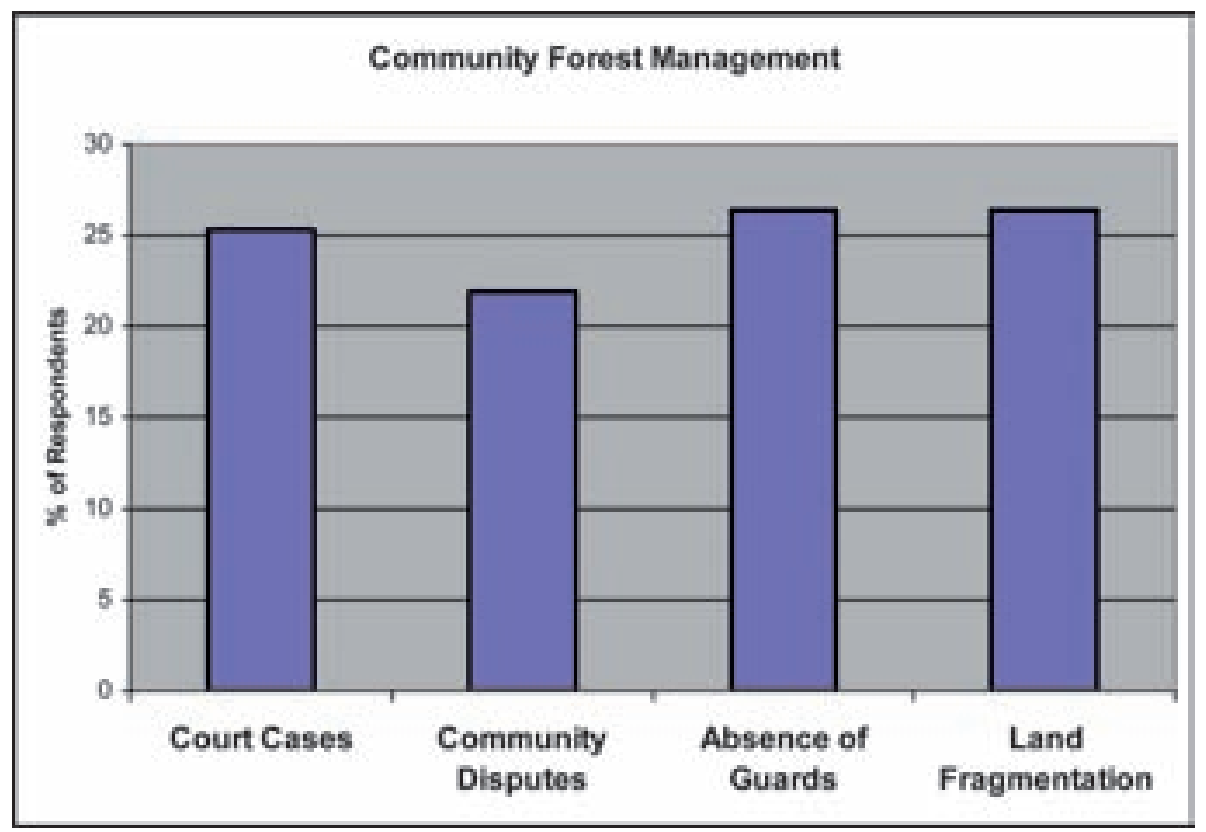

Fig 2. Causes for Brakedown of Community Forest Management 


\section{Traditional factors motivating the utilization of medicinal plants}

The traditional culture promotes free access to traditional health care delivery and religious beliefs. These factors influenced the use and trade in medicinal plants. The data in Table 3 revealed that medicinal plants occupied a central position in the social, cultural and economic lives of the rural people. The traditional culture of the various communities relied heavily on medicinal plants for their sustenance in terms of: recreation: ceremonies and festivals (24.7\%), employment generation (19.9\%), health care (18.6\%), income generation (18.5\%) and traditional religion (18.3\%) (Fig. 3).

Table 3. Factors influencing the utilization of medicinal plants

\begin{tabular}{|l|c|c|c|c|c|c|}
\hline \multirow{2}{*}{$\begin{array}{l}\text { Location of } \\
\text { respondents }\end{array}$} & \multicolumn{5}{|c|}{$\begin{array}{c}\text { Respondent views on factors in the utilization } \\
\text { of medicinal plants (\%) (N=110) }\end{array}$} & \multirow{2}{*}{ Total } \\
\cline { 2 - 6 } & $\begin{array}{c}\text { Income } \\
\text { generation }\end{array}$ & Employment & $\begin{array}{c}\text { Traditional } \\
\text { religion }\end{array}$ & Health care & Recreation & \\
\hline Abeokuta & 20 & 14 & 23 & 15 & 28 & 100 \\
Ado Ekiti & 16 & 28 & 12 & 23 & 21 & 100 \\
Akure & 19 & 14 & 17 & 22 & 28 & 100 \\
Benin & 18 & 16 & 24 & 18 & 24 & 100 \\
Calabar & 19 & 23 & 20 & 18 & 20 & 100 \\
Enugu & 26 & 22 & 19 & 18 & 15 & 100 \\
Ibadan & 20 & 19 & 18 & 22 & 21 & 100 \\
Oshogbo & 18 & 16 & 18 & 23 & 24 & 100 \\
Owerri & 14 & 28 & 17 & 21 & 12 & 100 \\
Uyo & 16 & 16 & 15 & 24 & 30 & 100 \\
Mean responses \% & 18.5 & 19.9 & 18.3 & 18.6 & 24.7 & 100 \\
\hline
\end{tabular}

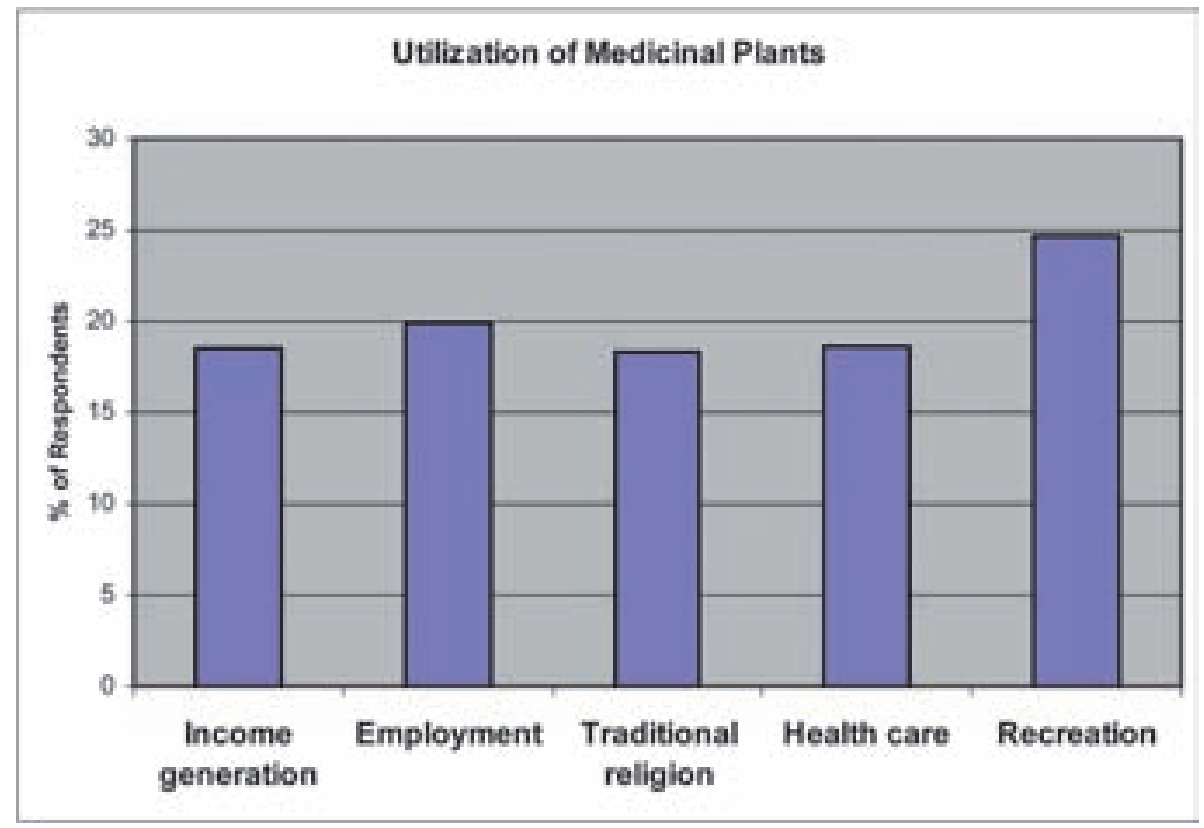

Fig 3: Factors Influencing the Utilization of Medicinal Plants 
Respondents indicated that the absence of key traditional medicinal plants was leading to postponement of some cultural festivals. For example, a traditional chief in Yoruba land cannot be installed in the absence of ewe ikoko (Newbouldia laevis). The culture in some communities demands that the drums and masks used for cultural festivals should be carved from sacred tree species: Triplochiton scleroxylon, Astonia congensis, Vitelaria paradoxum, Trichilia rubescen and Lawsonia inerms. The fire wood used for cooking foods used for rituals is derived from the followings species: Khaya ivorensis, K. granditolia, Alstonia boonei, A. congensis, Triplochiton seleroxylon, Bridelia ferruginea, Vitex doniana and Cordia millenii in some cultures. The species for cultural festivals are also used for curative and or magical purposes. These multiple uses mount pressure on choice species of medicinal plants.

\section{Traditional practices and medicinal plants}

Respondents in this survey indicated that the traditional practices influence uses of commercial based medicinal plants. Table 4 presents the views of respondents on the status of each of the 45 species in regular trade within the rainforest areas of Nigeria and revealed that: (i) habitat loss is the main impact of traditional practice on the medicinal trade (36.2\%). This was followed by over harvesting of medicinal plants (35.4\%) and extirpation of medicinal plants from the forests (28.4\%). (ii) Extirpation of species was an indication decline while habitat loss crated instability in the medicinal plant trade. (iii) Over harvesting of medicinal plants was an issue that had reduced the rate of species regeneration in natural forests.

\section{POLICY IMPLICATIONS}

The forests supplying medicinal plants were fragile and in decline. The traditional practices put in place to manage the forests are failing: regulations were difficult to enforce; management practices aimed at conserving the forests are broking down; and access rights is becoming a mere routine. Within the framework of these practices, the ecology of medicinal plants within their habitats is not promising for their domestication for the market: they are characterized with slow growth rate, irregular flowering and fruiting within and between species, low viability of seeds, scanty fruits, high rate of seed infestation on the forest floor and wide spread of stranglers on seedlings under canopy opening required for regeneration of seedlings in the forest floor [Lamprecht, 1978].

Challenges of in situ conservation of the species are an uphill task especially under difficult tenure regimes in place. Even in the face of these setbacks, ex situ conservation among stakeholders of medicinal plants is not bright. Many farmers are not motivated to raise market based medicinal plants in gardens due to financial constraints, lack of technical and silvicultural knowledge of plants and inadequate access to land [Osemeobo, 1990a]. Besides these are lack of infrastructures on which domestication of medicinal plants can be based. Policydecision makers can solve the problems by providing resources to: (i) document keystone species of medicinal plants in each ecological zones and their distribution status and uses; (ii) stimulate the interests of farmers to encourage them integrate growing of medicinal plants into the traditional farming system [Osemeobo, 1990b]; (iii) conduct regular research and training on the techniques of producing medicinal plants for the market in terms of the silviculture, management and harvesting; (iv) initiate establishment of community based medicinal farms, (v) analyse market chains and policies for resource planning, (vi) monitor and evaluate the status of medicinal plants in terms of profitability and acceptance as a viable land use and (vii) combine in situ and ex situ methods to conserve habitats where medicinal plants are harvested. 
Table 4. Impact of traditional practices on the status of medicinal plants regularly traded in Nigeria

\begin{tabular}{|c|c|c|c|c|}
\hline \multirow{2}{*}{$\begin{array}{l}\text { Status of medicinal plants } \\
\text { from natural forests }\end{array}$} & \multicolumn{4}{|c|}{$\begin{array}{l}\text { Respondents opinion on impacts of traditional culture on the status } \\
\text { of key medicinal plants on trade (\%). } N=110\end{array}$} \\
\hline & Habitat loss & Over harvesting & Extirpation & Total \\
\hline Canarium schweinfurthii & 35 & 32 & 33 & 100 \\
\hline Zingiber officinale & 21 & 43 & 36 & 100 \\
\hline Piper guineense & 48 & 34 & 18 & 100 \\
\hline Afromomum melagueta & 41 & 46 & 13 & 100 \\
\hline Xylopia aethiopica & 38 & 33 & 29 & 100 \\
\hline Tetrapluera tetraptera & 38 & 28 & 34 & 100 \\
\hline Ananthus montanus & 16 & 40 & 44 & 100 \\
\hline Ocimum gratissimum & 45 & 38 & 17 & 100 \\
\hline Hypoeses rosea & 12 & 43 & 45 & 100 \\
\hline Thorningia sanguine & 10 & 52 & 38 & 100 \\
\hline Khaya senegalensis & 23 & 48 & 29 & 100 \\
\hline Tetracarpidium conophorum & 11 & 52 & 37 & 100 \\
\hline Laggera alata & 41 & 46 & 13 & 100 \\
\hline Rauvolfia vomitoria & 38 & 5 & 57 & 100 \\
\hline Cocholospermum planchonni & 13 & 48 & 39 & 100 \\
\hline Solanum indicum & 48 & 42 & 10 & 100 \\
\hline Enantia chloratha & 45 & 38 & 17 & 100 \\
\hline Combretum smeathmanii & 55 & 38 & 7 & 100 \\
\hline Daniellia ogea & 48 & 48 & 4 & 100 \\
\hline Uraria picta & 16 & 45 & 39 & 100 \\
\hline Struchium spargonophora & 38 & 49 & 13 & 100 \\
\hline Rothmannia hispida & 29 & 54 & 17 & 100 \\
\hline Lophira procera & 51 & 43 & 6 & 100 \\
\hline Annona senegalensis & 36 & 16 & 48 & 100 \\
\hline Sansevieria berica & 28 & 55 & 17 & 100 \\
\hline Sanseuieria guineense & 11 & 28 & 61 & 100 \\
\hline Acanthus montanus & 47 & 27 & 26 & 100 \\
\hline Cissus aralioides & 29 & 14 & 57 & 100 \\
\hline Uvaria chamae & 46 & 50 & 4 & 100 \\
\hline Callichilia barteri & 24 & 27 & 49 & 100 \\
\hline Rauvolfia vomitoria & 48 & 34 & 18 & 100 \\
\hline Anchomanes difformis & 57 & 25 & 18 & 100 \\
\hline Marsdenia latifolia & 45 & 8 & 47 & 100 \\
\hline Spathodea campanulata & 34 & 48 & 18 & 100 \\
\hline Combretum racemosum & 49 & 6 & 45 & 100 \\
\hline Acanthospermum hispidum & 36 & 58 & 6 & 100 \\
\hline Aspilia africana & 35 & 19 & 46 & 100 \\
\hline Byrsocarpus coccineus & 32 & 51 & 17 & 100 \\
\hline Cnestis ferruginea & 35 & 42 & 23 & 100 \\
\hline Ipomoea involucrate & 53 & 45 & 2 & 100 \\
\hline Alchornea cordifolia & 45 & 29 & 26 & 100 \\
\hline Bridelia ferruginea & 50 & 7 & 43 & 100 \\
\hline Phyllantus muellerianu & 42 & 50 & 8 & 100 \\
\hline Dissotis graminicola & 39 & 55 & 6 & 100 \\
\hline Boerhavia coccinea & 48 & 10 & 42 & 100 \\
\hline Mean responses \% & 36.2 & 35.4 & 28.4 & 100 \\
\hline
\end{tabular}




\section{CONCLUSION}

Based on the results on which this study is based, it was clear that the traditional forest management practices were working against time. A central question is: should policy and decision makers gloss over the problems of conserving the forests that may jeopardize future generations in medicinal plant trade? We think not. It is well known that except the rural communities that depend on medicinal plants are directly involved in the conservation and management of the forests stability of the ecosystem cannot be realised. On this basis it is recommended that domestication of medicinal plants through stakeholder participation should be combined with enrichment planting within the forests.

\section{REFERENCES}

Chambers, P. (1999) Forests, cultures and conservation, pp. 345-395 in Ed. Poser, D.A. and Oxford Centre of Environment, Cultural and Spiritual Values of Biodiversity, Nairobi, 764 pp.

FME (2003) Nigeria national biodiversity strategy and action plan, Federal ministry of environment. Government printer, Abuja, 114 p.

Lamprecht, H. (1978) Desirability, potential and problems of natural regeneration in the tropics, Plants and Research development, N7, pp. 7-12.

NPC (2000) Nigeria demographic and health survey, national population commission, Abuja. Government Printer, Abuja, 102 p.

Osemeobo, G.J. (1990a) Why People Don't Grow Trees, A case Study of Nigerian Smallholders, Quarterly Journal of Agriculture N 29, pp. 303-319.

Osemeobo, G.J. (1990b) Land use policies and biotic conservation: problems and prospects for forestry development in Nigeria, Land Use Policy, N7, pp. 314-322.

Osemeobo, G.J. (1991) A financial Analysis of Forest Land Use in Bendel, Nigeria, Forest Ecology and Management, N 40, pp. 233-241.

Osemeobo, G.J. (1993) The Hazards of Rural poverty: Decline in Common Property Resources in Nigerian Rainforest Ecosystems, Journal of Environmental Management, N 38, pp. 201-212.

Osemeobo, G.J. (2001) Is Traditional Ecological Knowledge Relevant in Environmental Conservation in Nigeria? International Journal of Sustainable Development and World Ecology, N 8, pp. 203-210.

Osemeobo, G.J. (2005a) Living on wild plants: Evaluation of rural household economy in Nigeria. Environmental Practice, N 7, pp. 246-256.

Osemeobo, G.J. (2005b) Living on forests: Women and household security in Nigeria, Smallscale forest Economic Management and Policy, N 4, pp. 343-358. 
Osemeobo, G. J. (2008) An Assessment of the Supply Chain for Marketing Medicinal Plants from the Rainforest Region of Nigeria, Journal of Forest Products Business Research, N 5, pp. 1-15.

Osemeobo, G.J and Omeni, F.O. (2008) Trade and utilization of wild animals in traditional practices in Nigeria, International Journal of Economic and Development Issues, N 7, pp. 77-89.

Osemeobo, G.J. (2009a) Evaluation of land tenure and traditional culture in biodiversity conservation in Nigeria. International Journal of Soil Science, N 1, pp. 52-65.

Osemeobo, G.J. (2009b) Osemeobo G J. Economic Assessment of Medicinal Plant Trade in the Rainforest of Nigeria, Journal of Medicinal \& Spice Plants, N 14, pp. 71-176.

Sofowora, A. (1993) Medicinal Plants and Traditional Medicine in Africa. Spectrum Books Ltd., Ibadan. 289 p.

Posey, D. A. (1999) Culture and nature: the inextricable link, pp. 1-18 in Ed. D.A. Posey and Oxford Centre for the Environment, Cultural and Spiritual Values of Biodiversity, Nairobi, 764 pp.

Senanayake, R. (1999) Voices of the earth, pp. 119-166 in Ed. D.A. Posey and Oxford Centre for the Environment, Cultural and Spiritual Values of Biodiversity, Nairobi, 764 pp.

UNSN (2001) Nigeria common country assessment, United Nations System in Nigeria, Abuja, $54 \mathrm{pp}$.

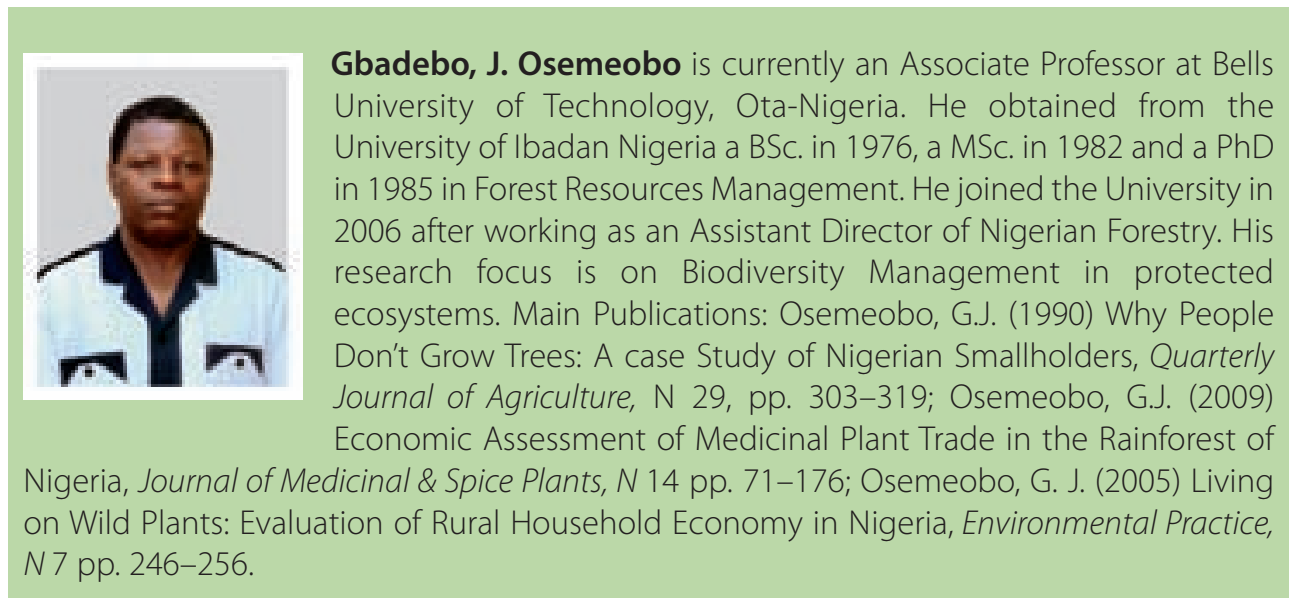


APPENDIX 1: QUESTIONNAIRE FOR THE SURVEY OF MEDICINAL PLANTS

Location

Name of settlement (town)

Name of market

Name of Respondent

Date of interview

\section{Demand for medicinal plants}

1. What do you understand as a medicinal plant in your community?

2. Name the 5 most popular plants in traded for traditional medicine in your community.

Medicinal plants (species)

Type of products (leaves, rots, flower, bark...)

1.

2.

\section{Supply of medicinal plants}

1. Where is the source of supply for the medicinal plants you use or sell?

2. How far is the source of medicinal plants from your village?

3. Has the distance of source of medicinal plants supply changed over the past 5 years? Yes No

4. What are the reasons for changes in distance travelled for the supply of medicinal plants supply?

\section{Traditional practices affecting medicinal plants}

1. Do medicinal plants have cultural importance in your community?

2. Give the cultural values of medicinal plants apart from healing

3. What type of land tenure is in vogue in your community?

4. What are the traditional methods of managing the forests?

5. What form of regulations is imposed on access to medicinal plants for trade?

6. Are access rights: (i) obey? (ii) Violated?

7. What are the causes of free-rider (violation of regulations) issues? 
8. Give reasons for your answers in N0 5 above

9. What are the regulations for harvesting medicinal plants for trade?

10. What is the cause of decline for each of the traditional medicinal plants you gave before using any of the followings: (i) habitat loss (ii)over harvesting (iii) extirpation (iv) abundance

\section{Sustainability of medicinal plants}

1. Is the use of medicinal plants popular in your village?

2. What is the importance of medicinal plants to your community?

3. Is the volume of medicinal plants Increasing? Decreasing? Stable?

4. Are the numbers of patients that patronise traditional healers? Increasing Decreasing Stable?

5. Do you own private herbal garden?

6. Will you support the community management of natural forest to conserve herbal plants?

7. If your answer to question 9 above is yes, how can communal conservation be strengthened?

8. Give the names of 5 medicinal plants that require urgent measures of conservation in your locality

9. Name 5 species of medicinal values that were common in the forests ten years ago that are locally extinct now

THANK YOU 